\title{
Training opportunities for older workers in the Netherlands: A Vignette Study
}

\author{
Kasia Karpinska ${ }^{a}$, Kène Henkens ${ }^{b, c, d, *}$, Joop Schippers ${ }^{e}$, Mo Wang ${ }^{\mathrm{f}}$ \\ a Department of Sociology, Erasmus University, Rotterdam, The Netherlands \\ b Netherlands Interdisciplinary Demographic Institute (NIDI-KNAW), The Netherlands \\ c Department of Sociology, University of Amsterdam, The Netherlands \\ d Department of Health Sciences, University Medical Center Groningen (UMCG), The Netherlands \\ e Utrecht School of Economics, Utrecht University, The Netherlands \\ ${ }^{\mathrm{f}}$ Department of Management, University of Florida, USA
}

\section{A R T I C L E I N F O}

\section{Article history:}

Available online 3 April 2015

\section{Keywords:}

Training opportunities

Older workers

Vignette study

\begin{abstract}
A B S T R A C T
Demographic changes and labor market challenges highlight the importance of lifelong learning and development for all employees. The current study analyzes the factors that may influence managers' propensity to offer older workers different kinds of training (specific or general). To investigate this question, a vignette study among 153 managers in Dutch organizations was conducted. Managers were randomly assigned into one of the four experimental conditions that involve a decision regarding specific or general training (aimed at internal or external mobility). The results suggest that managers perceive training incidences as a tool to increase productivity of older workers who perform well and are highly motivated, and far less as a tool to increase productivity of workers who need updating their human capital. The implication of these results is discussed.
\end{abstract}

(c) 2015 Elsevier Ltd. All rights reserved.

\section{Introduction}

Training is clearly essential for workers and organizations: it helps workers maintain and increase their employability, enhances their motivation and job satisfaction, and at the same time, also benefits the organizations that employ them (Becker, 1975). Aguinis and Kraiger (2009) pointed out that "as organizations strive to compete in the global economy, differentiation on the basis of the skill, knowledge, and motivation of their workforce takes on increasing importance," stressing the significance of updating workers' skills (Aguinis \& Kraiger, 2009; p. 452).

\footnotetext{
* Corresponding author at: Netherlands Interdisciplinary Demographic Institute (NIDI-KNAW), The Netherlands. Tel.: +31 0703565235.

E-mail address: henkens@nidi.nl (K. Henkens).
}

Several surveys of working populations in the European Union have focused on worker training activities and showed that approximately $39 \%$ of European adults participated in training (Dohmen \& Timmermann, 2010). The evidence suggests that the participation in training is rather voluntary, as only approximately $20 \%$ of respondents who followed training did so because it was obligatory (Dohmen \& Timmermann, 2010). The exact numbers of training participation vary per country, yet it is clear that training is not equally distributed between employees (Hanson, 2008). Employer-provided training is by far the most important source of further education and training after an individual enters the labor market (Hanson, 2008), which stresses managers' role in offering training opportunities. However, it is still unclear how managers arrive at their decisions regarding to whom such opportunities should be offered.

Different domains of social sciences have accumulated insights regarding various aspects of training. 
Psychological studies focus extensively on training design and transfer, its delivery and evaluation, and improvement of performance (e.g., Brown \& Sitzmann, 2011). Aguinis and Kraiger (2009) discuss comprehensively the benefits of training for individuals, teams and organizations, stressing the importance of knowledge transition and increased performance. The question of training participation is mostly framed in terms of needs assessment and workers' readiness to participate in training (defined as motivation and self-beliefs that are likely to influence willingness to attend training and learning during training) (Aguinis \& Kraiger, 2009). Economists focus mostly on returns to training and report consistently positive relationships between training participation and wages (e.g., Leuven \& Oosterbeek, 2004), and training and productivity (Barrett \& O'Connell, 2001; De Grip \& Sauermann, 2012). Lazear (1979, 1981) has put forward the argument that training activities aimed at increasing a worker's human capital require some kind of long-term employment relationship between employers and their workers, including some kind of delayed payment. Hutchens (1986, 1988, 1989) has elaborated on this idea, making a distinction between general and firm specific training. Especially firm specific training ties an employee to his/her firm and reduces older workers' mobility. The delayed payment that induces firm specific training, however, also reduces older workers' opportunities to be hired and increases the attractiveness of younger workers (Heywood, Jirjahn, \& Tsertsvardze, 2010). Finally, sociologists examine the patterns of participation, education and status attainment related to training (e.g., Rainbird, 2000). However, few previous studies from these research domains have focused on the distribution of training opportunities (i.e., who receives the training). Recently, Lazazzara, Karpinska, and Henkens (2013) have argued that not all older workers are offered equal opportunities when it comes to access to training and that highly qualified workers are much more likely to be offered training opportunities (also see Boehm \& Dwertmann, 2015). Following this observation, the current study aims to examine factors that may affect managers' decisions to grant training opportunities to older workers.

Participation in training is especially important for older workers (van Dalen, Henkens, \& Wang, 2015). An aging workforce requires older workers to prolong their working careers to assure sufficient labor market supply and the sustainability of social security systems. Training increases older workers' chances for retention: it offers older workers opportunities to maintain and enhance their employment potential and optimize their value in the labor market (Cully, VandenHeuvel, Wooden, \& Curtain, 2001; Organisation for Economic Co-operation and Development (OECD), 2006; van Dalen et al., 2015). Yet, a wide body of evidence suggests that training incidences decrease with age (Armstrong-Stassen \& Templer, 2005; Bishop, 1997; Zacher, 2015) and that employers' discriminatory attitudes and their perception of the productive potential of older workers form barriers to training (Cully et al., 2001). Many studies indicate that employers see older workers as inflexible, unwilling (or unable) to adapt to the changing work environment and less productive than their younger colleagues (van Dalen, Henkens, \& Schippers, 2010; Wang,
Olson, \& Shultz, 2012). Such discriminatory attitudes of managers can affect their decisions with respect to older workers (Chiu, Chan, Snape, \& Redman, 2001; Finkelstein, King, \& Voyles, 2015). The evidence suggests that managers are often not very positive in their evaluation of training for older workers (Loretto \& White, 2006), and conveys an idea that older workers are excluded from training based on their age (Eurobarometer, 2012). The research question we pose in this study is: What are the factors that affect training opportunities for older workers?

Something that complicates a comprehensive view of the factors that might influence training opportunities is the huge variety of types of training and the investments involved. Most studies report information on formal and specific training, i.e., training that can be applied only at the company that provides it (Becker, 1975; Leuven \& Oosterbeek, 1999). Yet, there is evidence suggesting that organizations frequently offer general training to their workers. Moreover, many studies on returns to training indicate that employers can choose from training that is offered within the company (i.e., free of charge) or outsource it to different organizations (Hanson, 2008). Less is known whether those differences affect managers' propensity to offer such opportunities to older workers. This study aims at examining training of older workers with a broader empirical basis by testing hypotheses on different types of training settings.

Our study contributes to the literature in three ways. Firstly, using a vignette design, this study examines which individual characteristics of older workers affect managers' decisions to offer training opportunities for older workers. Offering training is greatly affected by expected returns to that training. Human capital theory is a framework that will be applied to derive hypotheses on the impact of individual circumstances on training opportunities. Secondly, next to the effects of workers' characteristics, also restrictions present in the organizations and managers' characteristics are included in the analysis of the training opportunities. This focus offers comprehensive view on factors that affect training opportunities. Thirdly, we examine managers' propensity to offer older workers training in different training situations. These investigated conditions include whether the training is aimed at increasing skills in employees' current position or a different position, and whether the training is associated with significant financial cost. This allows us to examine training opportunities depending on their context.

\section{Theoretical background}

Organizations are often defined as goal-oriented systems that strive toward profit maximization, continuity, and maintaining a healthy market position (Kalleberg, Knoke, Marsden, \& Spaeth, 1996). Managers in organizations are supposed to contribute to these goals through, among other things, realization of high production levels and low costs, low absenteeism, good social relations and maintenance of useful sources of knowledge and contacts, and recruitment of qualified staff (Kalleberg et al. 1996). Employees' skills and knowledge are among the most important assets of organizations, and updating and 
upgrading them is essential to maintain a competitive advantage (Torraco, 2000). Training of staff members may be an important instrument when updating skills and knowledge.

\section{Individual characteristics}

Managers' decisions to grant training opportunities to their workers may include evaluation of workers' various individual characteristics. The economic approach applied to understanding managers' decisions can be captured with the human capital theory, which analyzes investments in human capital and rates of return of education and training (Becker, 1975). According to this theory, when deciding who to grant the training opportunities, managers often search for information that points toward individuals whose training will bring the best return. Human capital theory also predicts that skills and knowledge are likely to become obsolete over the life course, stressing the importance of lifetime investments in human capital (Becker, 1975). As such, training is viewed as a mean that improves workers' skills and enhances their productivity. Moreover, training is offered when the future benefits of the investments exceed direct and indirect cost of training (in terms of financial costs but also in terms of costs associated with absence from the workplace). The size of both categories of costs for the employer not only depends on the type of training, but also on the share of the costs borne by workers. If for instance workers take the training in their own leisure time, indirect cost for employers may be limited. In line with this theory, organizations should invest in skills-updating programs to prevent skills obsolescence and will profit from resulted higher employee productivity. There are studies that find evidence for the causal relation between training participation and increased productivity (De Grip \& Sauermann, 2012). This approach to training focuses on the factors that can limit productivity decline or increase returns to training investments, thus predicting that companies are more likely to offer training that is specific rather than general. While specific training is primarily useful at the company that offers it, general training can also be applied at other companies. In fact, previous research has found that participation in general training may increase the risk of employee turnover and loss of the investment (Acemoglu \& Pischke, 1998; Bishop, 1997).

Skill obsolescence is particularly likely to affect older workers, as they have experienced a high pace of technological change in the course of their careers. Various studies show that employers perceive obsolete skills to go hand-in-hand with lower productivity (Remery, Henkens, Schippers, \& Ekamper, 2003; Taylor \& Walker, 1994). As such, training will be particularly important for older workers who perform poorly to bring their performance up to organizational standards or refit them to taking a different, possibly less demanding position. Therefore, we predict that older workers who perform moderately well will be more likely to receive training opportunities than workers whose performance is higher (Hypothesis 1).

Performance is however not the only worker characteristic that will be evaluated in the current study. Human capital theory suggests that age also plays an important role in determining older workers' training. Different studies have shown that older workers are less likely to be offered training (see Bishop, 1997). In line with human capital theory, the direct and indirect costs of training are compared with the discounted future benefits of the human capital investment (Davies \& Elias, 2004). The lack of involvement in training older workers thus arises because of the limited period over which employers might reap a return to their investment. Consequently, we predict that managers will be less likely to offer training opportunities to older workers closer to retirement (Hypothesis 2).

Human capital theory predicts that investment in training will also be affected by older workers' health status. Mental strain is one of the main reasons for employee exit from the labor force (Wray, 2003). Both physical and mental health issues increase the risk of productivity loss and absenteeism, lowering the prospects of returns to the training investments, and can thus lead to turnover of older workers. Thus, consistent with the human capital approach to training, managers might be less likely to offer training opportunities to workers with frail health, in order to limit the risk of investment loss. Therefore, we predict that managers will be more likely to offer training opportunities to older workers who are in better physical and mental health (Hypothesis 3).

Moreover, workers' positive work attitude may also contribute to their likelihood of receiving training. A good work attitude signals professional motivation that contributes more effectively to organizational goals. This motivation has been described as "the willingness to exert high levels of effort toward organizational goals" (Robbins, 1993, p. 205). Motivation is the resource that has a longterm, positive effect on worker performance within an organization and contributes to higher productivity, organizational commitment and lower turnover risk (Mathieu and Zajac, 1990). Managers are likely to perceive older workers who are motivated as a valuable asset in their organizations. Therefore, positive work attitudes may be perceived as signaling better motivation to follow training and apply newly acquired knowledge in daily practice. Therefore, we predict that managers will be more likely to offer training opportunities to older workers displaying positive work attitude (Hypothesis 4).

\section{Managers' characteristics}

In their training choices managers may also be affected by normative age regarding older workers and these workers' participation in the labor force. Social norms are customary rules of behavior that coordinate human interactions and affect decisions (Coleman, 1990; Etzioni, 2000). In the current study we focused on perceived age norms regarding employment transitions (Settersten \& Hagestad, 1996). As indicated by van Solinge and Henkens (2007), retirement age norms illustrate the appropriate time to retire, and they affect retirement decisions of older workers. Previous research by Karpinska, Henkens, and Schippers (2013a, 2013b) has shown that age norms held by managers do affect their hiring and retention decisions regarding older workers, and form a barrier to prolonged employment. Similarly, managers' age norms about older 
workers' retirement are assumed to affect their offering of training opportunities for older workers. Higher age norms with respect to retirement imply a more positive attitude toward older workers and their labor market participation. This more positive outlook will also increase support for older workers' training and decrease discrimination of that group. In addition, managers that are more positive about employment at older ages will view training of older workers as a justified investment with probable positive returns. We therefore predict that the higher the age norms held by managers with respect to labor market participation of older workers, the more likely they are to offer training opportunities to older workers (Hypothesis 5).

\section{Training characteristics}

Offering training opportunities is presumably affected by the consideration of costs involved and the aim of training. As direct supervisors of workers, managers might be more likely to offer training that is aimed at increasing skills in a worker's current position than in a different one. Indeed, there is evidence suggesting that managers recommend training based on its utility for daily-performance tasks (Bishop, 1997). To contrast, offering training that targets several skills applicable in a different position may benefit the worker and the broader organization but another department will then recoup the return to that investment. Thus, we expect that managers will be more likely to offer training opportunities to older workers when training aims at updating skills for the position workers currently occupy than for a different position in the organization (Hypothesis 6).

Further, from the economic perspective, we expect that managers will be more likely to offer older workers training programs that incur lower costs, both direct and indirect (related to employees' absence from their workplace). This is consistent with the human capital theory's premise that managers will try to maximize cost-benefit ratio in matching training candidates with training programs. In the current study we deal only with the direct, financial cost and we expect that training cost will be negatively related to the likelihood for older workers to receive the training (Hypothesis 7).

\section{Research design}

To answer the research questions a survey and vignettes studies on training opportunities for older workers were developed. We collected the data by accessing the sample of the Longitudinal Internet Studies for the Social Sciences of Tilburg University (http://www.lissdata.nl/lissdata/). LISS is an Internet panel that consists of 5000 households in The Netherlands. These households were selected based on a true probability sample of households drawn from the population register by Statistics Netherlands. The data was collected in April/May 2010.

\section{Sample}

Our study was directed at managers. Based on the question: Do you supervise others?, a total of 700 LISS members (managers) were approached. The response rate was 73.6 per cent $(N=515)$. Although the study was aimed at different-level managers in organizations, not all of the respondents satisfied this condition. Further selection based on the question: What is your current occupation? eliminated 186 non-managers from the sample. These nonmangers included for instance teachers who said to be supervising children. The final eligible sample consisted of 238 managers who were responsible in their daily routines for employment decisions regarding their subordinates. Of this sample 153 managers participated in the vignette study that was analyzed in this paper. The other 75 managers answered questions that were parts of a different study. The sample consisted of 117 males and 36 females, and the mean age of respondents was 45.7 (range 24-65, $\mathrm{SD}=9.6$ ). For details, please see Table 1 .

\section{Procedures}

During a survey background information on managers was collected and a month later vignette studies were conducted. The basic item of the vignette study is a short description of a situation or a person, generated by combining characteristics randomly manipulated by the researcher (Ganong \& Coleman, 2006; Wallander, 2009). In our study, each participant was randomly assigned to one of the four experimental conditions and received a random sample of 5 vignettes that corresponded to that specified experimental condition.

\section{Measurements}

\subsection{Vignettes}

In this study various hypothetical older workers were described with several characteristics and the training situation was placed in a specific organizational context. In the set up managers were presented with vignettes where instruction explicitly mentioned that all workers were highly motivated to participate in training. Presumably, older workers are often unwilling to participate in training, which is an often-mentioned reason behind their low training participation (Armstrong-Stassen \& Templer, 2005; Cully et al., 2001; Taylor, 2008). Focusing only on motivated older workers helps distinguish managers' preferences with respect to training opportunities without the confounding effect of these workers' assumed lack of motivation. When interpreting the results one should keep in mind that employers' judgments have been measured under the rather favorable condition that older workers are motivated to participate in training. In case of a lack of motivation judgments are likely to be less favorable. We assume that there is no relation between older workers' willingness to engage in training and their productivity. On the one hand, one may argue that older workers who realize their productivity is low are highly motivated to engage in training. On the other hand, motivation for training may reveal a kind of eagerness to keep up with new developments and might therefore reflect high productivity. So, in general, the group of older workers in need of training because of low productivity may only partly coincide with 
Table 1

Descriptive statistics of the sample used in the data.

\begin{tabular}{|c|c|c|c|c|c|}
\hline & $N$ total & Min & Max & Mean\% & St. Dev. \\
\hline \multicolumn{6}{|l|}{ Dependent variable pooled analysis - data in vignettes } \\
\hline Training desirability & 765 & 1 & 11 & 4.84 & 2.47 \\
\hline \multicolumn{6}{|l|}{ Dependent variable per experiment } \\
\hline Training desirability (exp 1a: own position, 2 days, cost month's salary) & 200 & 1 & 11 & 4.48 & 2.34 \\
\hline Training desirability (exp 1b: own position, 10 days, free of charge) & 220 & 1 & 11 & 5.29 & 2.51 \\
\hline Training desirability (exp 2a: different position, 2 days, cost month's salary) & 170 & 1 & 11 & 4.82 & 2.37 \\
\hline Training desirability (exp 2b: different position, 10 days, free of charge) & 175 & 1 & 11 & 4.69 & 2.51 \\
\hline \multicolumn{6}{|l|}{ Training characteristics } \\
\hline Cost of training & 765 & 0 & 1 & 48.05 & \\
\hline Goal of training & 765 & 0 & 1 & 54.55 & \\
\hline \multicolumn{6}{|l|}{ Characteristics of respondents - data on respondents } \\
\hline Managerial position & 153 & & & & \\
\hline Higher supervisory positions & & 0 & 1 & 44.1 & \\
\hline Intermediate supervisory or commercial positions & & 0 & 1 & 40.9 & \\
\hline Supervisory manual workers & & 0 & 1 & 14.9 & \\
\hline Age (years) & 153 & 24 & 65 & 45.7 & 9.6 \\
\hline Male & 153 & 0 & 1 & 76.6 & \\
\hline Education (years) & 153 & 8 & 18 & 15.2 & 2.35 \\
\hline Job level of subordinates & 153 & & & & \\
\hline Low-skilled & & 0 & 1 & 18.9 & \\
\hline High-skilled & & 0 & 1 & 81.1 & \\
\hline Size of organization & 153 & 10 & 10,000 & 445.8 & 1228.5 \\
\hline Sector & 153 & & & & \\
\hline Industry & & 0 & 1 & 33.7 & \\
\hline Services & & 0 & 1 & 38.9 & \\
\hline Public & & 0 & 1 & 27.7 & \\
\hline Age norm & 153 & 50 & 80 & 63.9 & 6.20 \\
\hline
\end{tabular}

Source: LISS panel study.

the group of those who are highly motivated to participate in training.

The four experimental conditions differed with respect to goal of training and its costs $(2 \times 2)$. The instructions applied in each experiment are presented below:

(1a) The employee described below wishes to follow a 2day external training (cost of a month salary, paid by the employer) that is related to his/her current position. What is the chance that you would offer this training opportunity?

(1b) The employee described below wishes to follow a 10time 2-day external training that is related to his/her current position. The training is free of charge. What is the chance that you would offer this training opportunity?

(2a) The employee described below wishes to follow a 2day external training (cost of a month salary, paid by the employer) that is related to another position in your organization. What is the chance that you would offer this training opportunity?

(2b) The employee described below wishes to follow a 10time 2-day external training that is related to another position in your organization. The training is free of charge. What is the chance that you would offer this training opportunity?

Each manager rated each vignette on an 11-point scale, ranging from 1 (absolutely would not offer training opportunity) to 11 (absolutely would offer training opportunity). For an example of a vignette used in the study, see Fig. 1.
Although each experiment referred to a different type of training, all vignettes consisted of the same variables and their respective levels. The eight vignette characteristics were: financial situation of the organization (solid/moderate); physical health condition (good/not very good); mental health condition (good/limited); work scope (works 5 days a week/works 3 days a week); older worker's performance (very good, good, moderate) and older worker's work attitude (positive/negative). In the vignettes we also included older worker's age (50, 54, 58, 62 and 66) and workers' gender (male/female). Given all possible combinations of the variables and their respective levels, a universe of 960 unique vignettes was created (i.e., $2 \times 2 \times 2 \times 2 \times 3 \times 2 \times 5 \times 2$; for details see Table 2). Variables measured in vignette experiments were included in the analysis as dummy variables. Except for the variable performance, where a new dummy was constructed that combined the answers "good" and "very good" into one category, all other dummy variables represent the level of each factor.

\section{Survey}

A month before the experiments were conducted, answers to questions on age norms and background characteristics of managers were collected. Existing age norms are measured on the basis of the open question: At what age do you consider a person too old to work in your organization for 20 hours a week or more? This question was previously used in a representative survey of European employers (Henkens \& van Dalen, 2012). The answer ranged from 


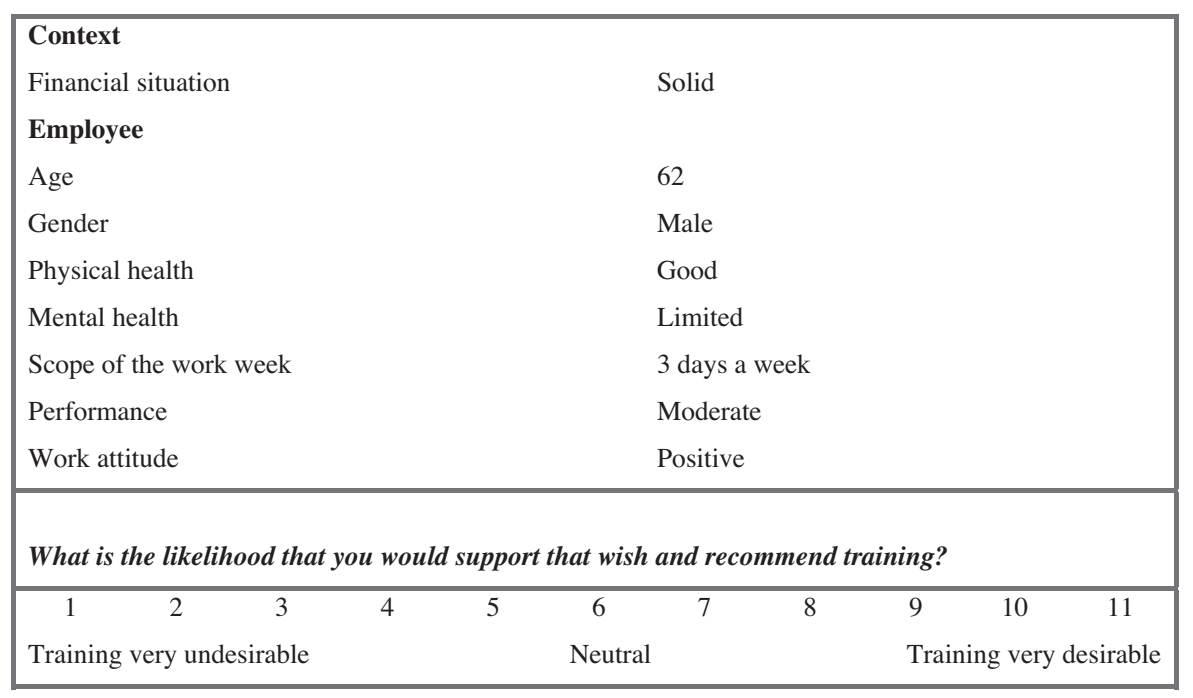

Fig. 1. Example of a vignette applied in Experiment 1a.

Table 2

Organizational contexts and employee attributes in the vignette.

\begin{tabular}{ll}
\hline Item & Categories \\
\hline Organization & \\
Financial position of the organization & Solid \\
& Moderate \\
Employee & \\
Age & 50 \\
& 54 \\
& 58 \\
& 62 \\
Gender & 66 \\
& Male \\
Physical health & Female \\
& Good \\
Mental health & Not very good \\
& Good \\
Scope of the work week & Limited \\
& 5 days a week \\
Performance & 3 days a s week \\
& Very good \\
Work attitude & Good \\
& Moderate \\
\hline
\end{tabular}

Source: LISS panel study.

40 to 100 . The mean of the age in the total sample was 63.9 years with an SD of 6.2. Modal value of age was 65 - approximately 32 percent of respondents indicated that the retirement age of 65 is when a person is too old to work $20 \mathrm{~h}$ or more.

In the analysis we controlled for organization's financial situation, as investing in older workers' skill-updating programs will be advocated if organizations can accommodate additional expenditures. This variable was included in vignettes. Sector of the organization was based on the question: In which sector is your company operating? Following the European Commission division of sectors, three categories were constructed: industry, services and public.
During this study the control variables respondents' gender and respondents' age were also collected.

\section{Analyses}

Before conducting the analysis, two aspects of the data need to be taken into account. In a vignette studies, the unit of analysis is the vignette (Ganong \& Coleman, 2006). As each manager in his respective experiments judged five vignettes, our data have a hierarchical structure by design, therefore observations are not independent (Wallander, 2009) and multilevel models need to be applied to deal with the hierarchical structure of the data (Hox, 2002). The dependent variable applied in this study is measured on an 11-point scale, with answer ranging from 1 ('absolutely would not offer training opportunity') through 6 ('neutral value') to 11 ('absolutely would offer training opportunity'). These answers are ordinal rather than numerical and therefore ordered probit models are desired tool for data analysis. Taken into account those specificities of our data we have estimated order probit models form hierarchical data using meoprobit command in STATA 13. Specifically, level-2 predictors consisted of managers' age norms and their demographic characteristics, sector of the organization and type of training. Level-1 predictors consisted of individual attributes of older workers that were included in the vignettes in the analysis we evaluated factors that affect managers' propensity to offer training opportunities to older workers.

Two models were estimated. In Model 1 we tested our hypotheses on the impact of characteristics of older workers on training opportunities. Model 2 included characteristics of managers and organizations in the assessment of training opportunities as level-2 predictors. In this model we also included the dummy variables representing different trainings to test whether training types affected managers' offerings of training opportunities. The variable cost denoted training that amounted to a month's salary and took two days (reference category was 
training that was free of charge and took 10 days to complete). The variable goal referred to the purpose of training and denoted training aimed at increasing qualification in the same position (reference category was training aimed at increasing skills for a different position in the same organization).

\section{Results}

Table 3 presents the results of the analyses (cut offs not presented). Model 1 includes individual characteristics of workers. On of the central questions is how older workers' performance is related to training opportunities. The results show that moderate work performance does not lead to higher chances of receiving training opportunities which contradicts the Hypothesis 1 . We hypothesized that training opportunities will decrease with older workers' age (Hypothesis 2) and their deteriorating health (Hypothesis 3 ). The results show that workers' age is negatively associated with receiving training opportunities; workers who are 62 and 66 years old were less likely to be offered the training opportunity comparing to those who are 50. Also, workers at this age were less likely to receive training when compared to workers aged 54 and 58. Also, good physical and mental health increased the participation chances. In line with Hypothesis 4, positive work attitudes enhanced managers' propensity to offer training opportunities. In our study we also controlled for workers' gender and the scope of the contract. Full-time employees were more likely to be offered training. No difference was found in how training opportunities were offered to male or female employees.

In Model 2 characteristics of managers and the organization were added to the model. None of the effects of individual characteristics of older workers previously included in the model changed substantially. We observe that in organizations that enjoyed a solid financial situation managers were more likely to offer training opportunities to their older staff members. Training opportunities were lower in both the industry and service sectors compared to the public sector. Neither age norms nor managers' gender had a significant effect on their training opportunities Yet, the likelihood of offering training opportunities to older workers decreased with managers' age.

In this study we also aimed at distinguishing between the training opportunities in different training types; training aimed at upgrading skills applicable in the position that workers occupy and also training targeting internal mobility of older workers. Also different cost schemes were included in the design. The results in the second column of Table 3 show that managers' decisions did not differ across training aimed at different positions or at cost involved in training.

\section{Discussion}

Although training of older workers is often seen as key practice to increase labor market participation of older workers (OECD, 2006), there is only limited insight into what factors affect managers' decisions regarding training opportunities for older workers. This is surprising, given the fact that managers are the gate keepers when it comes to offering training to their staff; they carry the responsibility for employability of their personnel and define training opportunities. The study is the first to analyze training opportunities for older workers among managers. Vignettes studies were designed to answer the research question. The data was collected among a sample of 153 managers in various Dutch organizations and multilevel models were estimated.

Human capital theory predicts that managers are more likely to offer training when they expect higher returns to the investment or when they intend to lower the risk of productivity decline due to skills deterioration. In line with this hypothesis, workers closer to their retirement and less healthy have fewer training opportunities. Training opportunities clearly decreased with age, and the impact of poor health also followed an expected pattern. Our study shows that older workers who perform well and are characterized by a positive work attitude have more training opportunities. Earlier studies found similar results for training participation (e.g., Arulampalam \& Booth, 1997, for young British women and men, and Renaud, Lakhdari, \& Morin, 2004, for a service organization in Canada). Arulampalam, Booth, and Bryan (2004) find for several European countries a negative association between fixed-term contacts and training participation, particularly for men, In addition, in most countries, and for both sexes, training is positively associated with high educational attainment. All these studies seem to point in the direction that training participation is less for those who might need it most. However, these studies do not make a distinction between training opportunities and actual participation, which makes it impossible to determine whether the actual cause for nonparticipation lies with a lack of opportunities from the side of the employer or reluctance from the side of the employee to seize the opportunity.

Workers who are not performing well are much more likely to be excluded from training. This might be an indication that managers do not take responsibility for the development of such workers and may be interpreted as a form of disengagement on the part of supervisors. Combined with the evidence from research by Damman, Henkens, and Kalmijn (2013) on older workers' disengagement prior to retirement, our findings thus suggest that the process of work disengagement takes place among both older workers and their managers.

We have examined in more detail training opportunities for different types of training and costs involved than is usually the case. Next to specific training aimed at the worker's current position, we have also looked at general training targeted at skills acquisition for internal mobility. Contrary to our expectations, no significant differences were found for either training aim or cost involved. There are several possible explanations of these findings. On the one hand, one might assume that there is indeed no difference in how managers evaluate different types of training. This might be because the distinction between different types of training cannot always be made so sharply. Another explanation might be that - just like other studies have shown with respect to child care and leave opportunities granted to workers (Schippers, Remery, \& van 
Table 3

Ordered probit model for hierarchical data explaining training opportunities for older workers.

\begin{tabular}{|c|c|c|c|c|}
\hline & \multicolumn{2}{|l|}{ Model 1} & \multicolumn{2}{|l|}{ Model 2} \\
\hline & Coef. & $t$-Score & Coef. & $t$-Score \\
\hline \multicolumn{5}{|c|}{ Employee's characteristics (Level 1 predictors) } \\
\hline \multicolumn{5}{|c|}{ Worker's age } \\
\hline 50 years old (ref.) & - & - & - & - \\
\hline 54 years old & -0.11 & -0.81 & -0.11 & -0.80 \\
\hline 58 years old & -0.04 & -0.27 & -0.05 & -0.41 \\
\hline 62 years old & $-0.38^{* *}$ & -2.80 & $-0.38^{* *}$ & -2.85 \\
\hline 66 years old & $-0.92^{* * *}$ & -6.96 & $-0.92^{* * *}$ & -7.01 \\
\hline Physical health good (ref. not good) & $0.43^{* * *}$ & 5.02 & $0.42^{* * *}$ & 4.99 \\
\hline Mental health good (ref. not good) & $0.31^{* * *}$ & 3.69 & $0.31^{* * *}$ & 3.70 \\
\hline \multicolumn{5}{|l|}{ Performance } \\
\hline Moderate & $-0.50^{* * *}$ & -5.52 & $-0.50^{* * *}$ & -5.50 \\
\hline Very good or good (ref.) & - & - & - & - \\
\hline \multicolumn{5}{|l|}{ Work attitude } \\
\hline Positive & $1.10^{* * *}$ & 12.21 & $1.10^{* * *}$ & 12.23 \\
\hline Negative (ref.) & - & - & - & - \\
\hline Male (ref. female) & 0.01 & 0.20 & 0.02 & 0.28 \\
\hline \multicolumn{5}{|l|}{ Work scope } \\
\hline 5 days a week & $0.31^{* * *}$ & 3.56 & $0.33^{* * *}$ & 3.86 \\
\hline 3 days a week (ref.) & - & - & - & - \\
\hline \multicolumn{5}{|c|}{ Organisation's characteristics (Level 1 predictors) } \\
\hline \multicolumn{5}{|c|}{ Financial situation } \\
\hline Solid & & & $0.20^{*}$ & 2.37 \\
\hline Moderate (ref.) & & & - & - \\
\hline \multicolumn{5}{|l|}{ Sector } \\
\hline Industry & & & $-0.66^{* *}$ & -2.67 \\
\hline Services & & & $-0.67^{* *}$ & -2.82 \\
\hline Public (ref.) & & & - & - \\
\hline \multicolumn{5}{|c|}{ Manager's characteristics (Level 2 predictors) } \\
\hline Age norm & & & 0.03 & 1.37 \\
\hline Male & & & 0.23 & 1.07 \\
\hline Manager's age & & & $-0.03^{*}$ & -2.37 \\
\hline \multicolumn{5}{|c|}{ Training cost and form (Level 2 predictors) } \\
\hline Cost a month salary & & & -0.20 & -1.06 \\
\hline Free of charge (ref.) & & & - & - \\
\hline Oriented on own position & & & 0.13 & 0.72 \\
\hline Oriented at different position (ref.) & & & - & - \\
\hline Constant & $3.94^{* * *}$ & 16.67 & $3.65^{* * *}$ & 2.22 \\
\hline \multicolumn{5}{|l|}{ Random effects } \\
\hline Variance level 2 & \multicolumn{2}{|c|}{$1.256(6.40)$} & \multicolumn{2}{|c|}{$1.091(6.24)$} \\
\hline$N$ of vignettes ( $N$ of respondents) & \multicolumn{2}{|c|}{$765(153)$} & \multicolumn{2}{|c|}{$765(153)$} \\
\hline
\end{tabular}

Source: LISS panel study.

Notes: in parentheses: $t$-score for variance components.

* $p<0.05$.

** $p<0.01$

${ }^{* * *} p<0.001$.

Doorne-Huiskes, 2003) - employers do not make very detailed calculations with respect to the exact costs and benefits of different types of training. On the other hand, supporters of Acemoglu and Pischke (1999) might point to the fact that general training is not offered by firms in perfectly competitive markets. However, the Netherlands is characterized by a high degree of market imperfections. This might induce employers to offer their employees general training as long as hiring/firing costs (labor market frictions) are sufficiently high. Another possibility is that the design of the study was not sufficiently detailed to reflect the differences in training types present in real life organizational settings. Given the importance of the training for older workers, future studies might further develop the impact of differences in training types, and costs on training opportunities.

Surprisingly, age norms held by managers did not affect their evaluation of training opportunities for older workers. Karpinska and colleagues, applying a similar experimental approach, have shown that perception of limits for employment influence managers' judgment of retention and hiring of older workers (Karpinska et al., 2013a, 2013b). Our findings complement this work and suggest that managers' evaluations and decisions regarding the development of the employability of their staff are less influenced by cultural norms regarding older workers than decisions regarding recruitment and retention. 
Although upgrading skills is an investment that benefits both workers who participate in training and the organization that employs them, costs of employer-provided training are usually compensated by organizations. Our finding that training investments are dependent on the organization's financial situation, might have important implication in view of the current financial crisis. We found strong support for the notion that organizations that are affected by the economic downturn reduce their training investments and put less emphasis on the development of the employability of their older staff members. Our findings that training opportunities were lower in the service and industrial sectors than in the public sector reflects the historical fact that on average in the Netherlands direct public sector wages have been lower than those in the private sector, while secondary terms of employment in the public sector have usually been better. This historical fact can be explained from the situation that public sector organizations in general have to make less sharp calculations regarding training costs and benefits than most private organizations. Moreover, to some extent public and political pressure may also require public sector organizations to set a good example and be more generous to offer training opportunities to workers than private organizations. Arulampalam et al. (2004) find similar effects for other European countries. Ceteris paribus this should put public sector organizations in a better position to increase older workers' actual retirement age than private organizations, because the training activities help to counter the depreciation of workers' skills.

The study was carried out in the Netherlands, where a recent policy change enforces extending working lives until the age of 67. In general, participation rates in training are relatively high; approximately 53 per cent of workers indicate having participated in some form of training over a period of two years (Borghans, Fouarge, \& de Grip, 2011). Yet, the participation rates decrease sharply after workers turn 50; approximately 35 per cent of 60 years old workers participate in training (Borghans et al., 2011). Although the presented results offer a valuable insight into training of older workers, future research should reveal to what extent our results can be generalized to countries with different legal arrangements. In the Netherlands as well as the other European countries mandatory retirement regulations are widespread, while in the United States mandatory retirement because of age is not allowed. Mandatory retirement may reduce training opportunities for older workers, because of the limited period employers may reap the returns to their investments. Future research must show the extent to which the conclusions drawn in this study also hold in situations where no mandatory retirement age exists.

We conclude with some methodological remarks. We designed four vignette experiments to look at various training forms for older workers. By designing experiments that regard each of the conditions separately, we ensure the quality of the data. Had type of training and cost been included as factors in vignettes, a random selection of vignettes might have resulted in lower representation of certain conditions in the final sample. We perceive this distinction as a noteworthy strength of our study. One has to keep in mind, however, that we asked managers to assess hypothetical situations. In real-life training situations managers may act or decide differently. Yet, the respondents were managers employed in organizations and not students, as is often the case in experimental studies (Barr \& Hitt, 1986). Consequently, the results of the study are more generalizable than earlier studies on employment decisions.

As already mentioned, we postulated that all vignettes included workers who were highly motivated to participate in training activities. This implies that employers' judgments recorded in this article are the most favorable judgments possible. If older workers are less motivated or not motivated at all employers will probably be less inclined to grant them training opportunities too. This suggests that from a policy perspective aimed at increasing older workers' knowledge and skills the situation is probably even worse than one could conclude based on the relatively favorable conditions we used in our experiment.

Despite those limitations, this study adds to the long-standing debate in the field of human resources management on relations between training and productivity of older workers. Our findings contradict the assumption that training is offered by managers to those workers who might need it the most to enhance or recover their lost productivity (OECD, 2006). The political rhetoric on the importance of lifelong learning and recommendations that follow (CEC (Commission of the European Communities), 2000; OECD, 2003) do not reflect the complexity of the decision-making processes that take place in the organizations. What is the least sure is that those workers who need the training the most are the ones to be offered it.

\section{References}

Acemoglu, D., \& Pischke, J. S. (1998). Why do Firms train? Theory and evidence. Quarterly Journal of Economics, 113(1), 79-119.

Acemoglu, D., \& Pischke, J. S. (1999). Beyond Becker. Training in imperfect labour markets. Economic Journal, 109(453), F112-F142.

Aguinis, H., \& Kraiger, K. (2009). Benefits of training and development for individuals and teams, organizations, and society. Annual Review of Psychology, 60, 451-474.

Armstrong-Stassen, M., \& Templer, A. (2005). Adapting training for older employees: The Canadian response to an aging workforce. Journal of Management Development, 24(1), 57-67.

Arulampalam, W., \& Booth, A. L. (1997). Who gets over the training hurdle? A study of the training experiences of young men and women in Britain. Journal of Population Economics, 10, 197-217.

Arulampalam, W., Booth, A. L., \& Bryan, M. L. (2004). Training in Europe. Journal of the European Economic Association, 2(2-3), 346-360.

Barr, S. H., \& Hitt, M. A. (1986). A comparison of selection decisionmodels in manager versus student samples. Personnel Psychology, 39(3), 599-617.

Barrett, A., \& O'Connell, P. J. (2001). Does training generally work? The returns to in-company training. Industrial and Labor Relations Review, 54(3), 647-662

Becker, G. S. (1975). Human capital, a theoretical and empirical analysis with special Reference to education (2nd ed.). New York: Columbia U.P.

Bishop, J. (1997). What we know about employer-provided training: A review of the literature. Research in Labor Economics, 16, 19-87.

Boehm, S. A., \& Dwertmann, D. J. G. (2015). Forging a single-edged sword: Facilitating positive age and disability diversity effects in the workplace through leadership, positive climates, and HR practices. Work, Aging and Retirement, 1, 41-63.

Borghans, L., Fouarge, D., \& de Grip, A. (2011). Een leven lang leren in Nederland No. ROA-R-2011/5. Maastricht: Researchcentrum voor Onderwijs en Arbeidsmarkt (ROA), School of Business and Economics, Maastricht University. 
Brown, K. G., \& Sitzmann, T. (2011). Training and employee development for improved performance. In S. Zedeck (Ed.), APA handbook of industrial and organizational psychology, Vol. 2: Selecting and developing members for the organization. APA handbooks in psychology (pp. 469-503). Washington, DC, USA: American Psychological Association.

CEC (Commission of the European Communities). (2000). A memorandum on lifelong learning. Brussels, Belgium: European Commission.

Chiu, W. C., Chan, A. W., Snape, E., \& Redman, T. (2001). Age stereotypes and discriminatory attitudes towards older workers: An East-West comparison. Human Relations, 54(5), 629-661.

Coleman, J. (1990). Foundations of social theory. Cambridge, MA: Belknap Press.

Cully, M., VandenHeuvel, A., Wooden, M., \& Curtain, R. (2001). Barriers to training of older workers, and possible policy solutions. No. Analysis and Equity Branch, Commonwealth. Department of Education, Training and Youth Affairs.

De Grip, A., \& Sauermann, J. (2012). The effects of training on own and co-worker productivity: Evidence from a field experiment. Economic Journal, 122(560), 376-399.

Damman, M., Henkens, K., \& Kalmijn, M. (2013). Late-career work disengagement: The role of proximity to retirement and career experiences. Journal of Gerontology: Social Sciences, 68(3), 455-463.

Davies, R., \& Elias, P. (2004). Employer provided training within the European union: A comparative review. In C. Sofer (Ed.), Human capital over the life cycle. A European perspective. Edward Elgar.

Dohmen, D., \& Timmermann, D. (2010). Financing adult learning in time of crisis. Brussels: EU Knowledge System for Lifelong Learning.

Etzioni, A. (2000). Social norms: Internalization, persuasion, and history. Law E Society Review, 34(1), 157-178.

Eurobarometer. (2012). Active ageing. Special eurobarometer. No. 378 Brussels: Directorate-General for Employment, Social Affairs and Inclusion.

Finkelstein, L. M., King, E. B., \& Voyles, E. C. (2015). Age metastereotyping and cross-age workplace interactions: A meta view of age stereotypes at work. Work, Aging and Retirement, 1, 26-40.

Ganong, L. H., \& Coleman, M. (2006). Multiple segment factorial vignette designs. Journal of Marriage and the Family, 68(2), 455-468.

Hanson, B. (2008). Job-Related Training and Benefits for Individuals. A review of evidence and explanations. OECD Education Working Papers No. 19

Henkens, K., \& van Dalen, H. P. (2012). The employer's perspective on retirement. In M. Wang (Ed.), The Oxford handbook of retirement (pp. 215-228). New York, NY

Heywood, J. S., Jirjahn, U., \& Tsertsvardze, G. (2010). Hiring older workers and employing older workers: German evidence. Journal of Population Economics, 23, 595-615.

Hox, J. (2002). Multilevel analysis: Techniques and applications. Mahwah, NJ: Erlbaum.

Hutchens, R. M.(1986). Delayed payment contracts and a firm's propensity to hire older workers. Journal of Labor Economics, 4(4), 439-457.

Hutchens, R. M. (1988). Do job opportunities decline with age? Industrial and Labor Relations Review, 42(1), 89-99.

Hutchens, R. M. (1989). Seniority, wages and productivity: A turbulent decade. Journal of Economic Perspectives, 3(4), 49-64.

Kalleberg, A. L., Knoke, D., Marsden, P. V., \& Spaeth, J. L. (Eds.). (1996). Organizations in America: Analyzing their structures and human resource practices. Thousand Oaks, CA: Sage.

Karpinska, K., Henkens, K., \& Schippers, J. (2013a). Retention of older workers: Impact of managers' age norms and stereotypes. European Sociological Review, 29(6), 1323-1335.

Karpinska, K., Henkens, K., \& Schippers, J. (2013b). Hiring retirees: Impact of age norms and stereotypes. Journal of Managerial Psychology, 28(7/8), 886-906.

Lazazzara, A., Karpinska, K., \& Henkens, K. (2013). What factors influence training opportunities for older workers? Three factorial surveys exploring the attitudes of HR professionals. International Journal of Human Resource Management, 24(11), 2154-2172.
Lazear, E. P. (1979). Why is there mandatory retirement? Journal of Political Economy, 87(6), 1261-1284.

Lazear, E. P. (1981). Agency, earnings profiles, productivity, and hours restrictions. American Economic Review, 71(1), 6-20.

Leuven, E., \& Oosterbeek, H. (1999). Demand and supply of work-related training: Evidence from four countries. Research in Labor Economics, $18,303-330$.

Leuven, E., \& Oosterbeek, H. (2004). Evaluating the effect of tax deductions on training. Journal of Labor Economics, 22(1), 461-488.

Loretto, W., \& White, P. (2006). Population ageing and older workers: Employers' perceptions, attitudes and policies. Population Space and Place, 12(5), 341-352.

Mathieu, J. E., \& Zajac, D. M. (1990). A review and meta-analysis of the antecedents, correlates, and consequences of organizational commitment. Psychological Bulletin, 108(2), 171-194.

Organisation for Economic Co-operation and Development (OECD). (2003). Beyond rhetoric, adult learning policies and practices. Paris, France: OECD.

Organisation for Economic Co-operation and Development (OECD). (2006). Live longer, work longer. Paris, France: OECD.

Rainbird, H. (2000). Skilling the unskilled: Access to work-based learning and the lifelong learning agenda. Journal of Education and Work, 13(2), 183-197.

Remery, C., Henkens, K., Schippers, J., \& Ekamper, P. (2003). Managing an aging workforce and a tight labor market: Views held by Dutch employers. Population Research and Policy Review, 22(1), 21-40.

Renaud, S., Lakhdari, M., \& Morin, L. (2004). The Determinants of Participation in Non-Mandatory Training. Industrial Relations, 59(4), 724 743.

Robbins, S. P. (1993). Organizational behavior: Concepts, controversies and applications (6th ed.). Englewood Cliffs, NJ: Prentice-Hall.

Schippers, J. J., Remery, C., \& van Doorne-Huiskes, A. (2003). Family friendly policies in the Netherlands: The tripartite involvement. Personnel Review, 32(4), 456-473.

Settersten, R. A., \& Hagestad, G. O. (1996). What's the latest? II. Cultural age deadlines for educational and work transitions. Gerontologist, 36(5), $602-613$.

Taylor, P. (2008). Are European older workers on the verge of a 'golden age' of employment opportunities? In A. Chiva, \& J. Manthorpe (Eds.) Older workers in Europe (pp. 38-52). Maidenhead, UK: Open University Press.

Taylor, P. E., \& Walker, A. (1994). The aging workforce - Employers attitudes towards older-people. Work Employment and Society, 8(4), 569-591

Torraco, R. J. (2000). A theory of knowledge management. Advances in Developing Human Resources, 2(1), 38-62.

van Solinge, H., \& Henkens, K. (2007). Involuntary retirement: The role of restrictive circumstances, timing, and social embeddedness. Journals of Gerontology Series B - Psychological Sciences and Social Sciences, 62(5), S295-S303.

van Dalen, H. P., Henkens, K., \& Schippers, J. (2010). Productivity of older workers: Perceptions of employers and employees. Population and Development Review, 36(2), 309-330.

van Dalen, H. P., Henkens, K., \& Wang, M. (2015). Recharging or retiring older workers? Uncovering the age-based strategies of European employers. Gerontologist (in press)

Wallander, L. (2009). 25 years of factorial surveys in sociology: A review. Social Science Research, 38(3), 505-520.

Wang, M., Olson, D., \& Shultz, K. (2012). Mid and late career issues: An integrative perspective. New York: Psychology Press.

Wray, L. A. (2003). Mental health and labor force exits in older workers: The mediating or moderating roles of physical health and job factors. In Michigan Retirement Research Center Research Paper No. WP-2003047. Ann Arbor, MI: University of Michigan.

Zacher, H. (2015). Successful aging at work. Work, Aging and Retirement, $1,4-25$. 